\title{
The Islamist vs the Islamic in Welfare Outreach
}

\author{
Emad Siam
}

Abstract Egypt's Islamist forces, in particular the Muslim Brotherhood, have been known for their broadbased populist base, one which was partly associated with their extensive welfare outreach. Yet how do we account for the disconnect between the Islamists and the youth uprisings at the wake of the revolution? This article argues that contrary to popular adages, the Islamists' welfare base had grown considerably weaker in the past decade due to security restrictions and internal fragmentation. Meanwhile, a new brand of Muslim organisations with a greater space for youth activism has emerged, and it is these youths who participated in their personal capacities in large numbers during the revolution and under their organisational umbrellas after the ousting of Mubarak. The case study of Islamist outreach presented here challenges some of the assumptions about the extent to which the Islamist welfare outreach translated into 'ownership' of the street. Ultimately, when the youth uprisings began, the Islamists, for all their networks, were just as disconnected from the street as other political and social forces.

\section{Introduction}

In Egypt, civil society organisations (CSOs) are for the most part engaged in charity relief and the extension of basic goods and services. Their role in contesting public policy or transforming societies to make them more politically aware of their rights has been very limited. However, in view of the severe restrictions on political activity imposed by the government (see Abd el Wahab, El Naggar, this IDS Bulletin), many political activists had turned to the formation of CSOs as the vehicle for political engagement. The leftists for example, became active in the establishment of human rights organisations and the Islamists became particularly active in religious-based organisations.

Within the Islamist movement, the two most prominent groups to have established organisations (formal and informal) for the extension of welfare services were the Muslim Brotherhood and the Salafis (ultraconservative Islamist groups).The Muslim Brotherhood work through locally based organisations, syndicates and student unions. The Salafis control large central organisations such as Ansar al Sunna al Muhamidiyya and El Gam'iyya el Shar'iyya. In this article, a distinction is made between organisations which deploy welfare services to advance their own political agenda and are labelled 'Islamist', and Islamic organisations which have a religious mantra but do not report to the political Islamist movement. While both have coexisted in the Egyptian context for a long time, this article begins by examining the role of Islamist welfare organisations which have conventionally had a dominance in the religious welfare sector and then discusses their increasing displacement by a new generation of religiousinspired welfare providers that do not have a direct link to the Islamist political forces.

Understanding these fundamental changes to the political landscape of service provisions helps challenge some of the assumptions about the nature of the populist base of the welfare arm of the Islamists.

\section{The rise and rise of Islamist outreach organisations}

It is difficult to determine the scale of Islamic and Islamist organisations in Egypt because of the obvious security restrictions on the association between welfare provision and political activity. One cannot determine the number of religious non-governmental organisations (NGOs) subject directly to the

IDS Bulletin Volume 43 Number 1 January 2012 (C) 2012 The Author. IDS Bulletin (c) 2012 Institute of Development Studies Published by Blackwell Publishing Ltd, 9600 Garsington Road, Oxford OX4 2DQ, UK and 350 Main Street, Malden, MA 02148, USA 
influence of political Islamic groups. According to Fahmy Howeidy (an intellectual with Islamist leaning), the number of Islamic charity associations in 1997 was 35 per cent of the total number of NGOs, although it is unclear how he arrived at such an estimate (Al Ahram, 14 January 1997).

One way to uncover the link between Islamist engagement and welfare is to look at the dual agency of Islamist figures, who are simultaneously known to be part of an Islamist group as well as being represented on the boards of these NGOs. Another way is through the security crackdowns on particular NGOs for their Islamist orientation and which are regularly taken up by the press.

The philosophy behind welfare provision is one of support in return for loyalty, which is part and parcel of the broader Islamisation of society. Overall, Islamist organisations are run in a topdown manner and their organisational leadership, membership and constituency reflect the political vision of the movements they belong to. Activities are run on the basis of providing support in return for loyalty. These activities may take the form of adopting Islamic behaviours that the Islamic movement seeks to spread (e.g. the Salafis impose the donning of the veil, growing the beard, praying regularly in the mosque) or take the form of collecting and distributing zakat (Islamic equivalent of tithing/alms) and charity and securing beneficiaries' votes in local and parliamentary elections. The latter occurs without any effort to raise the political conscience of the poor, but engages with them as repertoires of election votes.

The NGOs that are directly or indirectly subject to Islamist forces have been captured by the traditional local Islamist elites. The level of loyalty to these elites is often linked to the size and consistency of welfare support. The role of NGOs in building the influence of traditional groups, especially those who belong to the Muslim Brotherhood, could be observed through the link between their most prominent parliamentary candidates and NGOs.

The ability of the organisations to build a strong welfare foundation coincided with the state's demand for other actors to step in and provide socioeconomic services that the state was failing to provide; particularly under structural adjustment policies. The supply of substantial resources from the Gulf for the strengthening of Islamist activities made it possible for the Islamist welfare organisations to take on some of the welfare responsibilities. Funding came from formal and informal sources in the Gulf governmental, individual and associational. The latter includes the International Islamic Charity Organization, the Al Najaa Charity Association, Kuwaiti Beit al Zakat and others. Donations from the association of Kuwaiti Revival of Islamic Heritage can be used as an example: it is a Salafi association that channelled, in one instance in the 1990s, EGP500 million to a number of Islamic religious associations that were directly linked to the Islamism movement. This sum helped in building 12 Islamic centres, three health units, 42 Islamic libraries and a number of investment projects and mosques and this is just one model (Shobieb 1994). Moreover, prominence was given to zakat and its collection and distribution for charitable welfare purposes. ${ }^{1}$ Through the expansion of the Islamist welfare network, the state was able to mitigate the social tensions emanating from the negative socioeconomic impacts of structural adjustment. In turn, the Islamists were able to build an intellectual and public base within communities on a significant scale.

An analysis of the activities of 27 associations in 2004 (based in Cairo, Damietta from the Delta and Minya from Upper Egypt) showed that by far, the most frequent activity was the distribution of charitable handouts: financial or in-kind. This is followed by day-care centres and Koran recitation classes and training in sewing, welding or some other livelihood skill. Down the ladder was 'organising religious competitions and celebrations and the organisation of haj trips'.

While there was variation in some of the activities, overall there was usually a set 'menu' of activities that were offered across the different communities, irrespective of their local specificities.

With respect to welfare provision, many of the interventions offered in the 1980s and 1990s were in the health and education sectors. In education, the most common activity was the provision of classes for students enrolled in public schools at primary and secondary levels. These lessons were provided by the Islamist movement's youth, both university students and graduates. The enrolled 
students provided a core recruitment base for preparing girls and boys to become activists later at university stage. The extension of such educational services represented one of the most popular activities pursued by the Islamist NGOs by virtue of their indoctrination and constituencybuilding potential. Further, in view of the rapid deterioration of the quality of public education, many middle-class families (which represent the social base of the Muslim Brotherhood) chose to enrol their children in private schools (different types and levels). For example, in a field study in 2005, conducted on a sample of Alexandria university students, it was found that 50.6 per cent of the sample received their pre-university education in private schools. This result encouraged the Islamists (especially the Brotherhood) to expand educational investment to establish Islamic schools (Arabic/Language) in all spheres; whether owned by individuals linked to Islamist organisations or owned by Islamist NGOs. Examples are: schools of the Muslims Generation affiliated to the $\mathrm{Al}$ Tarbawia $\mathrm{Al}$ Islamyaa Association in Gharbia; schools and preschool day-care centres affiliated to Al Da'wa Al Islamiyya Association in Bani Suef; and schools and kindergartens affiliated to Gama'a Da'wat $\mathrm{Al}$ Haq Association. These schools were built to respond to the demand for good quality education by the upper tiers and restricted enrolment to Muslim students only. Most of the staff members of Islamic schools were Islamism activists who adopted a religious pedagogical approach to the education process, for example integrating Koran memorisation classes in their curriculum.

The main intervention pursued by Islamist organisations in the area of health was the establishment of outpatient health clinics, which offered clients treatment by a team of doctors from a diverse number of specialisations. Clients paid a nominal fee that was sufficient to cover the cost of running the dispensary. Many of these outpatient clinics were established locally by large organisations such as the Al Shar'iyya Association which had the resources to support such initiatives. In addition to dispensaries, many small Islamist NGOs were able to capitalise on their pool of doctors to send them on medical convoys to the villages. These convoys were popular and attracted much media attention. The cost of these convoys was low compared with establishing big specialised medical centres. Medical convoys were regularly organised by
Muslim Brotherhood activists to Misr Qadima in Cairo, ${ }^{2}$ Alexandria, ${ }^{3}$ Assuit ${ }^{4}$ and Ismailia. ${ }^{5}$

\section{The demise of the parallel Islamist welfare system}

By the beginning of the 2000s, the Islamists could no longer maintain their same distinctive mark in the community through welfare provision.

Endemic diseases among Egyptians were widespread and the state's role in providing free basic health provision had shrunk even further than the earlier decades. The Islamists simply could not fill an ever-growing gap in health needs, in particular since what was required were costly services that could not be provided through small outpatient clinics. Islamist NGOs such as the Al Shar'iyya Association invested vast sums in setting up large medical establishments for the treatment of cancer, kidney disease and so forth; however, it simply could not keep up with the ever-growing numbers. Similarly, in education, they had lost their competitive edge for other reasons, mainly because the provision of group tutorials became redundant. By the beginning of the decade (2000s) families preferred to send their children to the tutorial classes taught by school teachers at public schools in particular, since school teachers had the upper hand in passing or failing students (and they made no secret of it when providing after-school tutorial classes). The Islamist activists lost to a new cadre of professional teachers in the provision of tutorial classes at secondary level where parents were struggling to have their children make it to university. Organisations cut down on the group tutorials they offered. In the study conducted in 2004 on 27 associations, there were only three NGOs that were offering tutoring classes and two NGOs that had literacy classes. In terms of handouts, the role of Islamist welfare contributions had also shrunk from being regularly provided all year long to being reduced to special occasions such as at Ramadan and the Feast of Al Adha, and to emergency situations. Moreover, Islamist outreach no longer involved a wide plethora of interventions including youth-targeted cultural and social activities. They were down to the bare minimum of targeted hand-outs.

Moreover, in view of the increasing impoverishment of the Egyptian population, ${ }^{6}$ Islamists needed more resources to face shortcomings in social, health and educational services. However, the middle-class population also experienced 
deterioration in their social and economic status and this greatly affected the revenues available for responding to the growing deprivation. This was compounded by the increased restrictions laid on access to external funding.

The relatively relaxed political environment in which Islamist groups were allowed to expand and proliferate became increasingly restricted after the launch of the international campaign against terrorism following 9/11. The Egyptian government sought to suppress the Islamist activists through security and political and economic measures. The state froze the Muslim Brotherhood's economic activities, and investigations indicated that the financial cost of freezing 23 companies with 120 branches belonging to the Brotherhood amounted to EGP1.5 billion.

Such blows to the funding resources of the Muslim Brotherhood influenced its ability to support the funding of hundreds of NGOs. The Brotherhood was also faced with the task of funding the campaign processes in the run up to the elections, of 2005 and initial campaigning in 2010. ${ }^{7}$

Consequently, the Brotherhood redirected its funds to more targeted one-off hand-outs during Ramadan to potential voters in the phase prior to the elections. In the Misr al Qadima (Old Cairo), the electoral campaign coincided with Ramadan and the Feast of Al Adha. Zakat money was collected from the Muslim Brotherhood from within the constituency and distributed to nominated members or community development associations (CDAs) in a show of solidarity of the Brotherhood with the poor - and to remind them to give them their votes (activists pers. comm. 2011).

By the mid-2000s, the Muslim Brotherhood had adopted a clear strategic direction in favour of redirecting resources from a broad set of NGOs to the local Muslim Brotherhood candidate running for the 2005 elections. This direction was partly to focus the funds and partly because the NGOs which had provided them with a cover were becoming ever more subject to security harassment. For example, the Al Shar'iyya Association, which was known to be a Salafi organisation, had gradually become a refuge for Muslim Brotherhood activists in the 1990s. However, in order to block their increasing takeover, the security apparatus empowered the Salafis to rise against the Muslim Brotherhood and 'reclaim' their organisation.
There are a number of other factors that led to the waning of the Islamists' lustre in welfare outreach. The fact that they had a standard menu of activities that were provided irrespective of their local relevance made some question the efficacy of their outreach. It was a crisis of innovation in engaging with local realities as much as it was a crisis of the absence of new blood in these organisations, which had ignored the possibilities that youth may have something to contribute.

The exit of youth from the Muslim Brotherhood also notably weakened the internal organisational capacities of the movement, which impacted on their affiliated welfare-providing associations. A deep rift had already emerged within the Muslim Brotherhood between the Old Guard and the younger generations and which weakened the internal organisational strength. There has been a long-standing struggle between those who were faithful to the politicised al da'wa (prosletisation) role of the Muslim Brotherhood and those that wished to separate the politics from the da'wa and preferred to focus on building the profile of the movement as a political movement. The latter group which had a significant youth backing wished to engage in activism that went beyond the work based on charitable work. Many youths within the Brotherhood had become dissatisfied with the existing leadership and how they engaged. This led to the exit of many of the middle cadres of the movement, particularly after the January 25 th revolution. The exit of the middle rank youth from the Brotherhood undoubtedly weakened the welfare CSOs affiliated to the movement.

\section{Is there an Islamic alternative to the Islamist welfare NGO?}

A number of factors gave rise to the emergence of an alternative to the Islamist-led charity associations that also focused on working with the socioeconomically marginalised. First, many youths who wanted to become active in community service did not want to be associated with the Islamist political project out of fear that they would be subject to security harassment from the government. In other words, they did not want to acquire 'a security file' with the security investigations apparatus. The youth who became volunteers in Islamist organisations suddenly found themselves vulnerable to 
continuous security scrutiny, and hence chose a number of 'exit' options: they left the organisations altogether, they restricted their level of involvement to the minimum, or they transferred financial and in-kind support on an occasional basis (such as during religious feasts, etc.). The situation became particularly uncomfortable for some youth volunteers when the NGOs became transformed into the platforms for winning candidates for the Islamist nominees through the indiscriminate and wide use of resources to bribe voters in the election.

Moreover, the Islamist organisations offered no opportunities for the youth to assume leadership positions within, because these NGOs were under the authority and influence of traditional leaders of the local elite. Youth were excluded from decision-making processes, especially since age was seen as a main criterion for eligibility to assume senior positions.

The new generation of Islamic organisations that were established during the 2000s spoke to the need for religious-inspired community engagement of the educated religious middleclass youth. These youth wanted to engage in charity to fulfil religious obligation and spiritual needs in order to fulfil their obligations towards the payment of zakat and to observe Islamic ordinances of fulfilling the mission as a Muslim. It allowed them to engage in direct activism without being associated with political Islamic groups. Moreover, it created spaces for providing activities that were unconventional, diverse and went beyond distributing food and goods. It allowed the middle-class to use their resources and to work in marginalised areas, which they would not have had access to had they not had an institutional umbrella for their work. Further, because they worked in districts other than their own, they did not act like local elites who were using the extension of welfare to build a political constituency.

Key examples of NGOs that embody this model of middle-class religious-inspired youth activism include: Resala, the Misr El Kheir Association, Dar El Orman and Son'a Al Hayat. These are briefly described below.

- Resala was established in 1999 by a group of students in the faculty of engineering and became formally established as an NGO in
2000. It has managed to attract large numbers of young people through its religious-inspired messages of giving and sharing. It now has 50 branches in all governorates and 100,000 volunteers, including a large number of women. Activities include providing classes in literacy, computer skills, language and support for groups with special needs such as street children, the elderly, the blind and those suffering from a disability.

- The Misr El Kheir Association came into being in 2007, with the aim of directing zakat money for community development, evident in its motto of 'Developing Human Being is our Task'. The fact that the association is chaired by the Grand Mufti of Egypt has paved the way for receiving financial support both from the government and businessmen. The association has expanded quickly and works nationwide in extending charity income generation but also in undertaking large-scale initiatives such as supporting the heart centre in Aswan with catheterisation equipment.

- Dar El Orman was established as a charity association in 1996 under the sponsorship of the Al Qabai family. In its mission, it focuses on 'doing good' and 'helping the needy', as part of the human religious duty. The association has 13 branches, including in the governorates of: Giza, Minia, El Bahiera, El Sharkia, El Fayoum, Assuit, Qana, Aswan, Beni Suef, Sohag, Kafr El Shiekh and Gharbia. While it uses religious discourse, its volunteers cross political and ideological lines. Dar El Orman became popular for its work on promoting sustainable rural livelihoods but has expanded to include highly unconventional initiatives such as a project to use stem cells in treating diabetes and supporting research to use nanotechnology in treating cancer.

- Son'a Al Hayat was established by the supporters of the Islamic preacher Amr Khaled, who has a television programme of the same name. Inspired by his interviews on it, the idea of organising initiatives to serve the community was formed. This NGO is the voice of the educated middle-class youth who are the main audience of Amr Khaled. The activists and members are committed ideologically and denominationally to the spirit of what has been called 'moderate Islam'; an umbrella term for those belonging to Islamic groups including the Muslim Brotherhood. 
A review of the different projects implemented by this new generation of religious-inspired associations suggests that they are large-scale organisations that operate on a nationwide level via local branches: but decision-making remains centralised. It is important to note that all these new generation organisations have been initiated with a 'godfather' figure behind them. These figures are from what can be called the moderate Islamic wave. They have high-profile personalities but do not get involved directly in the daily running of these NGOs.

The distinctive factor in these organisations compared with their Islamist counterparts, is in their ability to recruit volunteers in large numbers and with a very high level of youth involvement. Volunteers may engage in all kinds of activities, ranging from driving the sick; visiting an elder; reading or recording a book for the blind; being a brother to an orphanage. It should be taken into consideration that Islamist NGOs have had a much smaller pool of volunteers than the newer types of NGOs. In Resala for example, there are 10,000 volunteers, a number that well exceeds the taskforce of those who belong to the Muslim Brotherhood. In the previously mentioned study conducted on 27 local religious NGOs, it was found that only 14.8 per cent of the total sample depended on volunteering, while the rest relied on paid work or secondment from the Ministry of Social Affairs. The activities of these NGOs absorbed thousands of youths who do not live in poor neighbourhoods and were willing to volunteer without any ideological or security pressures. The fact that they work in other areas also prevented the development of patron-client relations or the mobilisation of the beneficiaries for supporting a particular political candidate. The activities do not seem to be directly intended to support the political agenda of any one party or movement. For example, there seems to be no instrumentalisation of assistance for directing beneficiaries to vote in any particular way. It is also evident in their support for constituents such as street children and the disabled, who do not have an electoral voice. This is in sharp contrast to the Islamist organisations that often focus many of their activities among the sections of the population that have voter power.

However, the organisations do rely on religious idiom and rhetoric, which are already very pervasive in Egyptian culture, to inspire youth to volunteer and to mobilise resources. It is also clear in slogans that sum up the essence of their mission, such as 'Your gateway to do good', 'Together we make life', 'The enjoyment of giving' and 'Our mission is to develop human beings'. Their activities represent the standard staple of religious-inspired charity, such as the distribution of food bags during Ramadan and meat for the El Adha Feast, and sponsorship of orphans. While some political Islamic groups use the same methods of traditional religious associations controlled by it, Islamic NGOs think that working in its associations is a political and religious duty. It also subjected such works to the prescriptions of political leadership and their definition of appropriate behaviour (such as wearing the veil for women, which then evolved into wearing the niqab and long white robe for men; no smoking; participation in regular group prayer in the mosque; boycotting all forms of artistic practices; prohibiting gender mixing). Such prescriptions clashed with the youth who had no intention of abandoning a 'modern way of living' in order to comply with the political leadership of these organisations. This difference contributed to the increase in the base of active volunteers in the new generation NGOs because they felt more at liberty.

Unlike the large politically oriented Islamist organisations which often keep their budgets clandestine, this newer generation of religious associations publicise their budgets widely in the press and media. They also follow a modern auditing system, which enjoys a high level of transparency and is subject to control and inspection. This is particularly appealing to middle-class and wealthy businessmen who wish to make charitable contributions in a transparent way, so that they do not become entangled in inadvertently contributing to the political activities of religious groups - and which would create conflict with the government. Not surprisingly, they have been able to mobilise large amounts of funding from sources that do not necessarily espouse the Islamist agenda and who feel more comfortable in supporting non-political activity.

While these organisations work within an overall religious framework, the absence of the endorsement of a particular political ideological movement has allowed it a certain level of flexibility in observance of religious prescripts. This has been particularly appealing for the 
upper and middle-class volunteers and supporters who do not have to conform to specific ways of engaging. For example, there is no gender segregation among the youth volunteers in the implementation of the activities, a characteristic of the work approach in the Islamist counterparts. However, despite the fact that a large number of girls and women have joined these organisations, they still continue to be dominated by men, particularly in leadership and decision-making processes. This is also partly because they continue to rely on Islamic religious cultural precepts in mobilising resources. Support and activities provided by these CDAs are not accompanied by any political propaganda or requests that impose on beneficiaries a commitment to an Islamic uniform or going to the mosque or having a beard. Accordingly, the activists in these associations have less conditional ties to volunteering.

Furthermore, what characterises this new generation of religious-inspired NGOs is that, in addition to extending charity and relief, they have also ventured into new territories in research, education, income generation and community development, which are a

\section{Notes}

1 To give a sense of the scope of resources that can be generated under the religious rubric: the 6,000 committees established for the collection of zakat, set up by the Nasser Social Bank, collected EGP2 billion during the fiscal year 2010/11. These committees are distributed throughout a large number of mosques that are affiliated to Islamist NGOs (www.alorsanews.com, the site of El Borsa newspaper, 20 August 2011). The zakat committees constitute a limited proportion of zakat and charity collection in Egypt. Moreover, money is collected directly from mosque goers. There may be 10,800 mosques independent of the Ministry of Waqf, except for 55,000 mosques (statement of El Waqf, undersecretary of El Tahrir newspaper, 20 August 2011).

\section{Reference}

Shobieb, A. (1994) Terrorism Funders, Cairo: El Helal Publishing House: 95 considerable shift from the staple menu approach of many of the Islamist organisations.

\section{Conclusion}

The general trend of the newer generation of Islamic NGOs continues to rise and the increasing demise of the Islamist NGOs is likely to continue. The fact that political Islamist forces now have the right to establish their own parties may mean that they will invest less in indirect pathways of political engagement through NGOs. How politicised religiousinspired associational support will become in the future is unknown. It is important to note however, that while it is impossible to argue that the volunteers are not political activists, it is safe to say that they distinguish between their political activity and their volunteer work. This corps of middle-class youth volunteers was the initiator of January 25 th revolution in their personal capacities (not under the institutional umbrella of their organisation). Yet, following the ousting of President Mubarak, many of these volunteers were present in Tahrir Square wearing the T-shirts and badges of their 17 NGOs, such as Resala volunteers, who launched a campaign to clean up the square.

2 www.ikhwanonline.com (accessed 9 December 2011).

3 http://forum.egypt.com (accessed 9 December 2011).

4 www.ikhwanonline.com (accessed 21 August 2011).

5 http://ikhwanismailia.com (accessed 23 May 2011).

6 The Chairman of the Central Agency for Public Mobilization and Statistics in Egypt mentioned that a study conducted in September 2010 in 4,040 villages affirmed that in the poorest 100 villages in Egypt, 76 per cent of the population live below the poverty line.

7 Until it withdrew from the elections due to wide-scale voter rigging.

8 Interview with activists in the Muslim Brotherhood in a dialogue with the researcher during the electoral campaign. 